\title{
PENGEMBANGAN METODE ELISA UNTUK MENDETEKSI RESPON IMUN SPESIFIK PADA IKAN NILA (Oreochromis niloticus) YANG DIVAKSINASI TERHADAP Aeromonas hydrophila DAN Streptococcus agalactiae
}

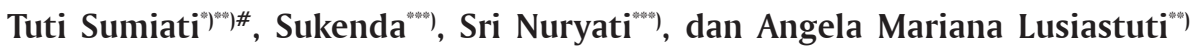 \\ ") Mahasiswa Pascasarjana Ilmu Akuakultur, Fakultas Perikanan dan Ilmu Kelautan, Institut Pertanian Bogor \\ ") Balai Penelitian dan Pengembangan Budidaya Air Tawar \\ -m) Departemen Budidaya Perairan, Fakultas Perikanan dan Ilmu Kelautan, Institut Pertanian Bogor
}

(Naskah diterima: 27 Maret 2015; Revisi final: 29 Mei 2015, Disetujui publikasi: 5 Juni 2015)

\begin{abstract}
ABSTRAK
Ko-infeksi bakteri Aeromonas hydrophila dan Streptococcus agalactiae rentan terjadi pada budidaya nila, sehingga pencegahan menggunakan vaksin koktail yang mengandung kedua bakteri tersebut merupakan langkah yang tepat untuk pengendaliannya. Penelitian ini bertujuan untuk menganalisa respon imun spesifik (antibodi) serum ikan nila yang divaksinasi dengan vaksin koktail A. hydrophila dan S. agalactiae dengan menggunakan ELISA. Penelitian dilakukan dalam dua tahap, tahap pertama adalah optimalisasi ELISA, yang terdiri atas persiapan antigen dan penentuan konsentrasi optimum antigen untuk deteksi antibodi dan tahap kedua adalah mendeteksi antibodi pasca vaksinasi ikan nila. Hasil penelitian menunjukkan bahwa konsentrasi optimum antigen $A$. hydrophila dan S. agalactiae untuk penentuan antibodi dalam ikan nila masing-masing sebesar $10 \mu \mathrm{g} / \mathrm{mL}$. Konsentrasi tersebut dapat digunakan untuk mendeteksi antibodi serum pada ikan nila setelah diberi vaksin koktail A. hydrophila dan S. agalactiae. Titer antibodi ikan nila pada minggu kedua sampai pada minggu kelima pada kelompok vaksinasi secara signifikan lebih tinggi dibanding kontrol $(\mathrm{P}<0,05)$.
\end{abstract}

KATA KUNCI: antigen, antibodi, ELISA, Aeromonas hydrophila, Streptococcus agalactiae

ABSTRACT: Development of ELISA method to detect specific immune response in nile tilapia (O. niloticus) vaccinated against A. hydrophila and S. agalactiae. By: Tuti Sumiati, Sukenda, Sri Nuryati, and Angela Mariana Lusiastuti

Co-infection of A. hydrophila and S. agalactiae susceptible in cultured tilapia, prevention using a cocktail vaccine containing both bacterias are the right step to control the diseases. The objectives of this study was to development of ELISA method to detect specific immune response in nile tilapia (O. niloticus) vaccinated against A. hydrophila and $S$. agalactiae. The study was conducted in two stages, the first stage was to optimized of ELISA, were consist of prepared and determined the optimum concentration of antigen for antibody detection and the second phase was to measured antibody tilapia. The results showed that the optimum concentration of both antigen A. hydrophila and S. agalactiae for determination of antibody in tilapia was $10 \mu \mathrm{g} / \mathrm{mL}$. The value concentration can used to detect antibody serum in tilapia post vaccination with cocktail vaccine against $A$. hydrophila and S. agalactiae. Antibody titers of vaccination group in the second week until the fifth week were significantly higher than controls $(P .<0.05)$.

KEYWORDS: antigen; antibody; ELISA; Aeromonas hydrophila; Streptococcus agalactiae

\section{PENDAHULUAN}

Budidaya ikan nila menyebar hampir di seluruh penjuru tanah air. Pesatnya intensifikasi budidaya tanpa disertai dengan pengelolaan lingkungan dan manajemen pakan yang baik mendorong peningkatan

\# Korespondensi: Mahasiswa Pascasarjana Ilmu Akuakultur, Fakultas Perikanan dan Ilmu Kelautan, Institut Pertanian Bogor. Jl. Rasamala, Kampus IPB Darmaga, Bogor 16680, Indonesia. E-mail: tuti.sumiati@yahoo.co.id kejadian penyakit. Kasus penyakit pada budidaya nila disebabkan oleh beberapa jenis patogen, salah satunya dari jenis bakteri. Bakteri yang teridentifikasi menginfeksi antara lain A. hydrophila dan Streptococcus sp. Akibat dari penyakit bakterial tersebut telah menjadi faktor penghambat pada peningkatan hasil produksi pada budidayanya (Supriyadi et al., 2005).

Bakteri A. hydrophila tersebar luas di perairan juga merupakan mikroflora normal pada ikan, namun apabila jumlahnya di perairan melebihi $10^{4}$ sel per 
mililiter maka dapat menjadi patogen (Irianto, 2003) dapat mengakibatkan kematian 10\%-70\% (Ibrahem et al., 2008). Sedangkan Lusiastuti et al. (2009) melaporkan bahwa kasus Streptococcosis di Waduk Cirata, Jawa Barat disebabkan oleh S. agalactiae, bakteri ini dapat mengakibatkan kematian yang tinggi sekitar 60\%-70\% (Siti-Zahrah et al., 2008; Toranzo et al., 2009). Keberadaan infeksi gabungan (ko-infeksi) penyakit ini pada ikan nila terjadi di KJA Waduk Cirata sebesar $20 \%$ dari populasi di karamba. Kedua bakteri ini memberikan gejala klinis pada ikan nila berupa pendarahan pada permukaan tubuh dan mata menonjol (Sugiani, 2012).

Pencegahan merupakan langkah paling ideal untuk pengendalian kasus penyakit pada budidaya ikan. Metode vaksinasi merupakan salah satu metode yang efektif dengan risiko yang kecil. Vaksinasi bertujuan untuk menginduksi imunitas jangka panjang dengan merangsang komponen dari respon imun spesifik (memori antibodi). Hasil beberapa penelitian menunjukkan bahwa terdapat perbedaan pada beberapa parameter imunitas seperti gambaran darah, indeks fagositosis, aktivitas lisosim, aktivitas komplemen, dan produksi antibodi spesifik pada ikan yang divaksin dibanding kontrol (Vivas et al., 2005; Tengjaroenkul \& Yowarach, 2009; Zheng et al., 2012; Sugiani et al., 2012).

Keberadaan respon imun spesifik ditunjukkan dengan peningkatan produksi antibodi pada ikan yang divaksin dan dapat dideteksi dengan beberapa metode yang sudah banyak dikembangkan, salah satunya adalah metode indirect-enzim linked immunosorbent assay (ELISA). Prinsip ELISA secara umum adalah mendeteksi adanya antibodi atau antigen dalam sampel. Adanya ikatan antara antigen dan antibodi yang berpasangan ditandai dengan menggunakan enzim spesifik dan dideteksi melalui penambahan substrat dan dapat dilihat secara visual melalui perubahan warna (Crowther, 1995), atau dengan bantuan alat yang dikenal dengan ELISA reader dengan panjang gelombang tertentu.

Penelitian ini bertujuan untuk melakukan pengembangan metode ELISA untuk mendeteksi respon imun spesifik pada ikan nila (O. niloticus) yang divaksinasi terhadap A. hydrophila dan S. agalactiae.

\section{BAHAN DAN METODE}

\section{Ikan}

Ikan uji menggunakan ikan nila (0. niloticus) berukuran 16,5 g \pm 3,4 yang berasal dari Instalasi Penelitian Plasma Nutfah Ikan Budidaya Air Tawar, Cijeruk. Berdasarkan penelusuran rekam jejak dari populasi ikan uji tidak ada riwayat terjadi kasus infeksi penya- kit dari bakteri target yaitu A. hydrophila dan S. agalactiae. Selain itu, selama masa aklimatisasi tidak ditemukan adanya gejala penyakit dari karakteristik yang akan muncul ketika terinfeksi penyakit MAS dan streptococcosis atau kondisi ikan sudah stabil.

\section{Vaksinasi dan Uji Tantang}

Vaksin koktail bakterin A. hydrophila dan S. agalactiae yang digunakan merupakan hasil gabungan vaksin monovalen dari masing-masing bakterin dengan konsentrasi $10^{11} \mathrm{CFU} / \mathrm{mL}$ dengan formulasi $25 \% \mathrm{~A}$. hydrophila dan 75\% S. agalactiae (Sumiati et al., 2012). Aplikasi vaksin dilakukan dengan teknik perendaman, dengan cara vaksin diencerkan terlebih dahulu dengan dosis $1 \mathrm{~mL}$ vaksin ke dalam $10 \mathrm{~L}$ air bersih. Vaksinasi ikan nila dilakukan terhadap dua kelompok, kelompok pertama ikan direndam dalam larutan vaksin yang sudah diencerkan selama 15-30 menit sambil diaerasi, untuk kontrol ikan direndam dalam air tanpa vaksin. Ikan dipelihara sampai minggu keenam, kemudian dilakukan vaksinasi ulang (booster) secara oral melalui pakan. Vaksinasi booster dilakukan selama lima hari dengan dosis $2-3 \mathrm{~mL} / \mathrm{kg}$ bobot ikan, kemudian ikan dipelihara kembali selama dua minggu. Untuk kelompok kedua, setelah ikan divaksinasi pada minggu ketiga dilakukan uji tantang dengan koinfeksi dengan bakteri aktif $A$. hydrophila $10^{8} \mathrm{cfu} / \mathrm{mL}$ dan S. agalactiae $10^{4} \mathrm{cfu} / \mathrm{mL}$. Ikan diinjeksi secara intra peritoneal sebanyak $0,1 \mathrm{~mL} /$ ekor, kemudian dipelihara selama 14 hari.

\section{Sampel Serum}

Kelompok pertama, pengambilan darah dilakukan sebelum vaksinasi dan dua minggu setelah booster. Serum yang dihasilkan digunakan sebagai kontrol negatif (sebelum vaksinasi) dan kontrol positif (setelah booster) pada optimalisasi ELISA.

Untuk kelompok kedua, pengambilan darah untuk koleksi serum dilakukan sebelum vaksinasi, dua minggu setelah vaksinasi, dan dua minggu setelah uji tantang, dan digunakan sebagai sampel pada uji ELISA. Sampel darah dikumpulkan dari empat ekor ikan untuk setiap kelompok vaksinasi dan kontrol. Darah diambil tanpa menggunakan anti-koagulan, dan serum yang diperoleh disimpan pada $-20^{\circ} \mathrm{C}$ sampai digunakan.

\section{Tahap I. Optimalisasi ELISA}

\section{Preparasi antigen dan ekstraksi protein}

Sumber antigen yaitu: bakteri $A$. hydrophila isolat AHL0905-2 dan S. agalactiae isolat $\mathrm{N}_{14} \mathrm{G}$ yang akan digunakan merupakan koleksi BPPBAT Kementerian Kelautan dan Perikanan. Bakteri A. hydrophila diinokulasi pada media Triptic Soy Agar (TSA) dan S. agalactiae diinokulasi pada media Brain Heart Infussion 
Agar (BHIA). Kemudian diinkubasi selama 24 jam, selanjutnya dipanen ke dalam $10 \mathrm{~mL}$ salin $0,85 \%$.

Sebagian dari masing-masing sediaan antigen dilakukan pengujian kepadatan bakteri (SNI: 01-2332. 3-2006), dan sebagian lagi disonikasi pada $40 \mathrm{~Hz}$ selama lima menit (on ice), selanjutnya disentrifugasi selama 60 menit pada $3.000 \mathrm{~g}$ dan suhu $4^{\circ} \mathrm{C}$ (Sugiani et al. 2014). Antigen siap untuk dilakukan pengukuran kadar protein (Bradford, 1976).

\section{Pengukuran konsentrasi dan titrasi protein}

Larutan standar protein dibuat larutan stok bovine serum albumin (BSA) dengan konsentrasi 1.000 $\mathrm{mg} / \mathrm{L}$, kemudian diencerkan sehingga diperoleh larutan stok BSA $100 \mathrm{mg} / \mathrm{L}$. Dari larutan stok tersebut dibuat pengenceran seri dengan konsentrasi $0,10,20$, 30, 40, 50, 60, 70, 80, 90, dan $100 \mathrm{mg} / \mathrm{L}$. Kemudian dilakukan pengukuran terhadap standar protein terlarut dengan menambahkan $0,1 \mathrm{~mL}$ seri larutan standar dengan $5 \mathrm{~mL}$ reagen Bradford, lalu divortex dan diinkubasi pada suhu ruang selama 10-60 menit, kemudian dibaca pada panjang gelombang $595 \mathrm{~nm}$. Dengan menggunakan regresi linear, akan didapatkan persamaan matematik untuk larutan standar protein yang diperoleh dari nilai absorbansi standar, yang akan digunakan pada pengukuran konsentrasi protein sampel.

Pengukuran konsentrasi protein sampel. Pengukuran sampel dilakukan dengan cara menambahkan $0,1 \mathrm{~mL}$ antigen dengan $5 \mathrm{~mL}$ reagen Bradford divortex dan diinkubasi pada suhu ruang selama 10-60 menit. Absorbansi larutan sampel protein dibaca pada panjang gelombang $595 \mathrm{~nm}$ (Bradford, 1976). Dengan persamaan matematik dari kurva standar protein, akan didapatkan kadar protein terlarut yang terkandung dari masing-masing antigen.

Optimalisasi konsentrasi antigen. Optimalisasi konsentrasi dilakukan dengan tujuan untuk mengetahui konsentrasi optimal antigen melalui titrasi protein (Lubis, 2013). Larutan buffer yang digunakan dalam penelitian ini adalah $0,1 \mathrm{M}$ karbonat-bikarbonat pH 9,6. Titrasi protein dilakukan mulai dari konsentrasi $40 \mu \mathrm{g} / \mathrm{mL}$ diencerkan serial 40, 20, 10, 5, 2,5 $\mu \mathrm{g} / \mathrm{mL}$ dimasukkan ke dalam sumur mikrotiter. Kemudian diinkubasi pada suhu $4^{\circ} \mathrm{C}$ selama semalam. Selanjutnya dilakukan uji indirect ELISA, sehingga dari nilai OD yang dihasilkan diperoleh konsentrasi antigen yang optimal digunakan untuk pengujian sampel antibodi serum ikan nila.

\section{Tahap II. Indirect enzime-linked immunosorbent assay}

Pengukuran titer antibodi sampel dilakukan dengan menggunakan metode indirect ELISA terhadap antigen-antibodi perlakuan. Metode yang dilakukan mengadopsi metode Pasnik et al. (2005), dan Sugiani et al. (2014) dengan menggunakan 96 sumur cawan mikrotiter. Konsentrasi antigen disesuaikan dengan hasil konsentrasi optimal. Setiap sumur dilapisi dengan $50 \mu \mathrm{L}$ dari masing-masing konsentrasi antigen A. hydrophila atau S. agalactiae yang diencerkan dalam $50 \mu \mathrm{L}$ buffer karbonat-bikarbonat $0,1 \mathrm{M}(\mathrm{pH} 9,6)$, kemudian diinkubasi selama satu malam pada $4^{\circ} \mathrm{C}$. Sumur mikrotiter dicuci dengan phosphate buffer saline (PBS pH 7,4) mengandung Tween-20 (PBS-T 0,05\%) kemudian ditutup dengan BSA 3\% dalam PBS, diinkubasi selama satu jam pada $25^{\circ} \mathrm{C}$ selanjutnya dicuci kembali dengan PBS-T 0,05.

Sampel serum ikan hasil perlakuan diencerkan 1:50 dengan PBS-T $(\mathrm{pH} \mathrm{7,2)} \mathrm{kemudian} \mathrm{ditambahkan}$ ke dalam sumur mikrotiter yang telah dilapisi antigen homolog, dengan tiga kali ulangan. Cawan diinkubasi pada $25^{\circ} \mathrm{C}$ selama satu jam dan dicuci dengan PBS-T 0,05. Imunoglobulin Rabbit Anti-Tilapia poliklonal antibodi $(1: 200$, dengan PBS-T pH 7,2) sebanyak $100 \mu \mathrm{L}$ ditambahkan ke dalam mikrotiter dan diinkubasi selama satu jam pada suhu $25^{\circ} \mathrm{C}$.

Peroksidase konjugat goat anti rabbit $\operatorname{IgG}$ diencerkan 1:5.000 kemudian ditambahkan sebanyak 100 $\mu \mathrm{L}$ ke dalam masing-masing sumur dan diinkubasi pada $25^{\circ} \mathrm{C}$ selama satu jam. Sumur mikrotiter dicuci dan ditambahkan one step ultra TMB-ELISA $100 \mu \mathrm{L}$ dan diinkubasi selama 20 menit pada suhu $25^{\circ} \mathrm{C}$. Reaksi dihentikan dengan menambahkan $100 \mu \mathrm{L}, 1 \mathrm{M} \mathrm{H}_{2} \mathrm{SO}_{4}$, dan cawan mikrotiter diinkubasi pada $25^{\circ} \mathrm{C}$ selama lima menit dan nilai optical density (OD) dicatat pada absorbansi $450 \mathrm{~nm}$.

\section{Analisa Data}

Data titer antibodi dianalisis dengan $t$ studenttest. Hasil pengujian dianggap signifikan pada nilai probabilitas $\mathrm{P}<0,05$.

\section{HASIL DAN BAHASAN}

\section{Tahap I}

Pelapisan antigen merupakan tahap pertama pada proses ELISA, dan ini merupakan proses ketika antigen dan antibodi yang sesuai dilarutkan dan diinkubasi hingga terabsorpsi pada permukaan sumur mikrotiter. Absorpsi terjadi secara pasif sebagai hasil interaksi hydrofobik antara rantai asam amino pada antigen atau antibodi yang digunakan untuk melapisi dan permukaan cawan mikrotiter. Hal itu tergantung pada waktu dan suhu inkubasi, pH buffer, dan konsentrasi antigen.

Hasil penghitungan kepadatan sel bakteri yang akan digunakan sebagai antigen untuk pelapis dipe- 
roleh nilai sebesar $1,84 \times 10^{11} \mathrm{cfu} / \mathrm{mL}$ untuk A. hydrophila dan $0,74 \times 10^{9}$ untuk $S$. agalactiae. Sedangkan hasil pengujian konsentrasi protein antigen dengan metode Bradford disajikan pada Tabel 1.

Antigen merupakan suatu bahan atau senyawa yang dapat merangsang pembentukan satu jenis atau lebih antibodi. Antigen ini dapat berwujud protein, lemak, dan polisakarida (Wibawan \& Soejoedono, 2013). Pada penelitian ini, hasil penghitungan kepadatan bakteri berbanding lurus dengan konsentrasi proteinnya. Berdasarkan data yang diperoleh diketahui bahwa baik kepadatan sel maupun konsentrasi protein pada antigen $A$. hydrophila lebih tinggi daripada konsentrasi protein antigen S. agalactiae. Data tersebut menunjukkan bahwa konsentrasi awal dari masing-masing antigen berbeda. Oleh karena itu, sebelum antigen tersebut digunakan untuk melakukan uji ELISA, maka harus dilakukan optimalisasi konsentrasi antigen terlebih dahulu.

Konsentrasi antigen yang optimal menjadi langkah penting dalam proses deteksi antibodi menggunakan ELISA. Hasil optimalisasi ELISA dinyatakan da-

Tabel 1. Konsentrasi protein antigen A. hydrophila dan $S$. agalactiae yang disonikasi

Table 1. Protein concentration of antigens A. hydrophila and $S$. agalactiae that was sonicated

\begin{tabular}{rc}
\hline $\begin{array}{c}\text { Antigen } \\
\text { Antigen }\end{array}$ & $\begin{array}{c}\text { Konsentrasi protein } \\
\text { Protein concentration }(\mathbf{m g} / \mathbf{m L})\end{array}$ \\
\hline A. hydrophila & 3.54 \\
S. agalactiae & 0.05 \\
\hline
\end{tabular}

lam bentuk konsentrasi optimal antigen hasil titrasi dengan konsentrasi yang sudah ditentukan. Hasil pengujian konsentrasi optimal antigen $A$. hydrophila dan S. agalactiae disajikan pada Gambar 1 dan 2.

Hasil yang diperoleh menunjukkan bahwa selisih nilai OD antara kontrol positif dan kontrol negatif paling tinggi diperoleh dari konsentrasi antigen 10 $\mu \mathrm{g} / \mathrm{mL}$ baik untuk $A$. hydrophila sebesar 0,3161 maupun $S$. agalactiae sebesar 0,2147 . Thuvander et al. (1987) menggunakan antigen dengan konsentrasi 10 $\mu \mathrm{g} / \mathrm{mL}$ antigen untuk deteksi Vibrio anguillarum pada trout pelangi. Estevez et al. (1994) hanya memerlukan $1 \mu \mathrm{g} / \mathrm{mL}$ untuk mendeteksi $V$. anguillarum pada turbot. Sedangkan Romstad et al. (2014) menggunakan $5 \mu \mathrm{g} / \mathrm{mL}$ untuk mengetahui potensi vaksin pada Atlantic salmon dengan melakukan uji serologis bakteri $A$. salmonicida. Konsentrasi antigen tergantung jenis antigen yang dipakai, antigen dari jenis protein umumnya memerlukan konsentrasi yang lebih kecil dibandingkan dari lipid ataupun karbohidrat. Crowther (1995) menjelaskan bahwa konsentrasi antigen optimal sebagai pelapis cawan mikrotiter yang digunakan pada metode indirect ELISA berada di kisaran 1-10 $\mu \mathrm{g} / \mathrm{mL}$.

Estimasi konsentrasi antigen sangat penting dalam uji ELISA, pada kondisi antigen berlebih maka proses penempelan antigen-antibodi tidak maksimal, sehingga antibodi akan terlepas dan terbuang pada saat pencucian. Begitu juga jika antigen yang berfungsi melapisi permukaan cawan dalam jumlah yang kurang, maka permukaan cawan lebih banyak yang kosong sehingga antibodi yang ditambahkan tidak maksimal berikatan dengan antigen. Oleh kare-

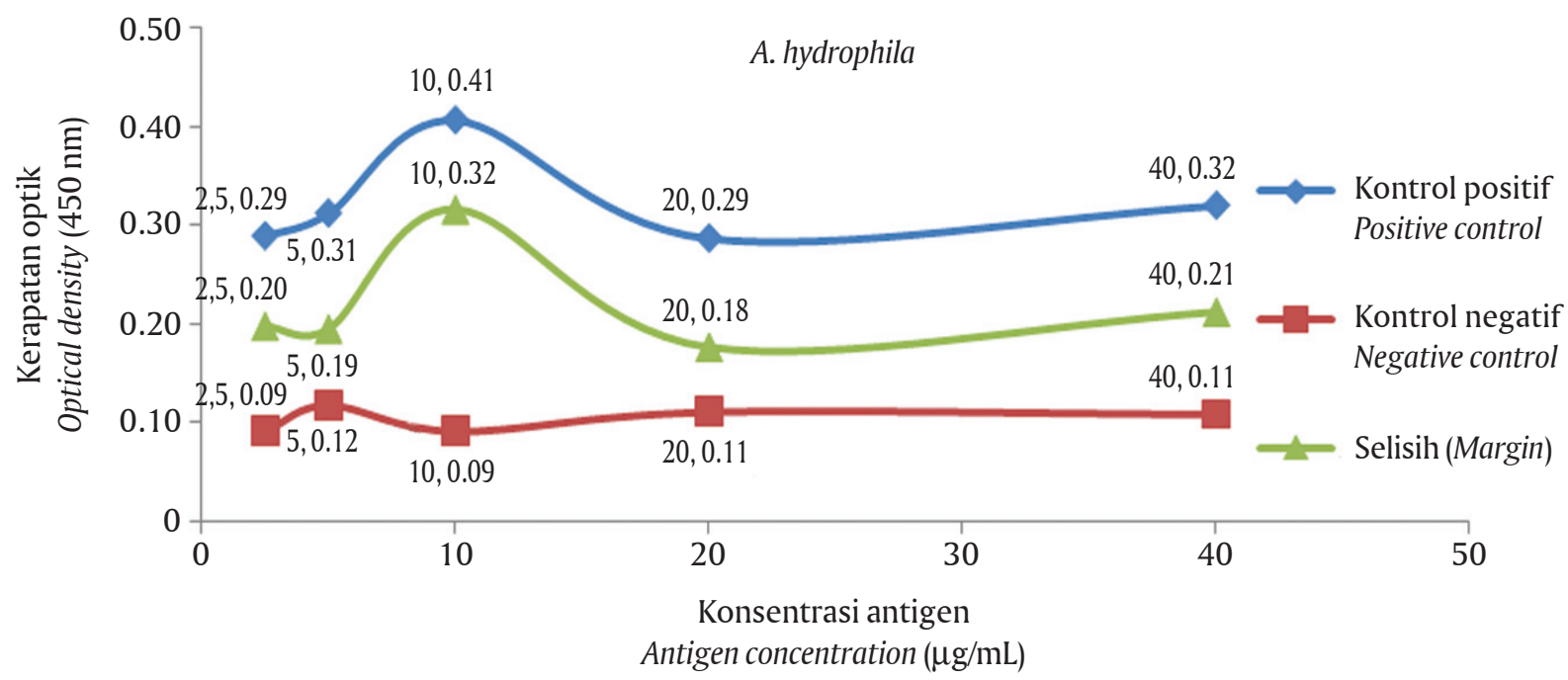

Gambar 1. Nilai OD ELISA serum kontrol positif dan kontrol negatif ikan nila (0. niloticus) pada berbagai pengenceran antigen $A$. hydrophila

Figure 1. The value of OD ELISA for positive and negative controls serum of tilapia (O. niloticus) at various dilutions of antigen of A. hydrophila 


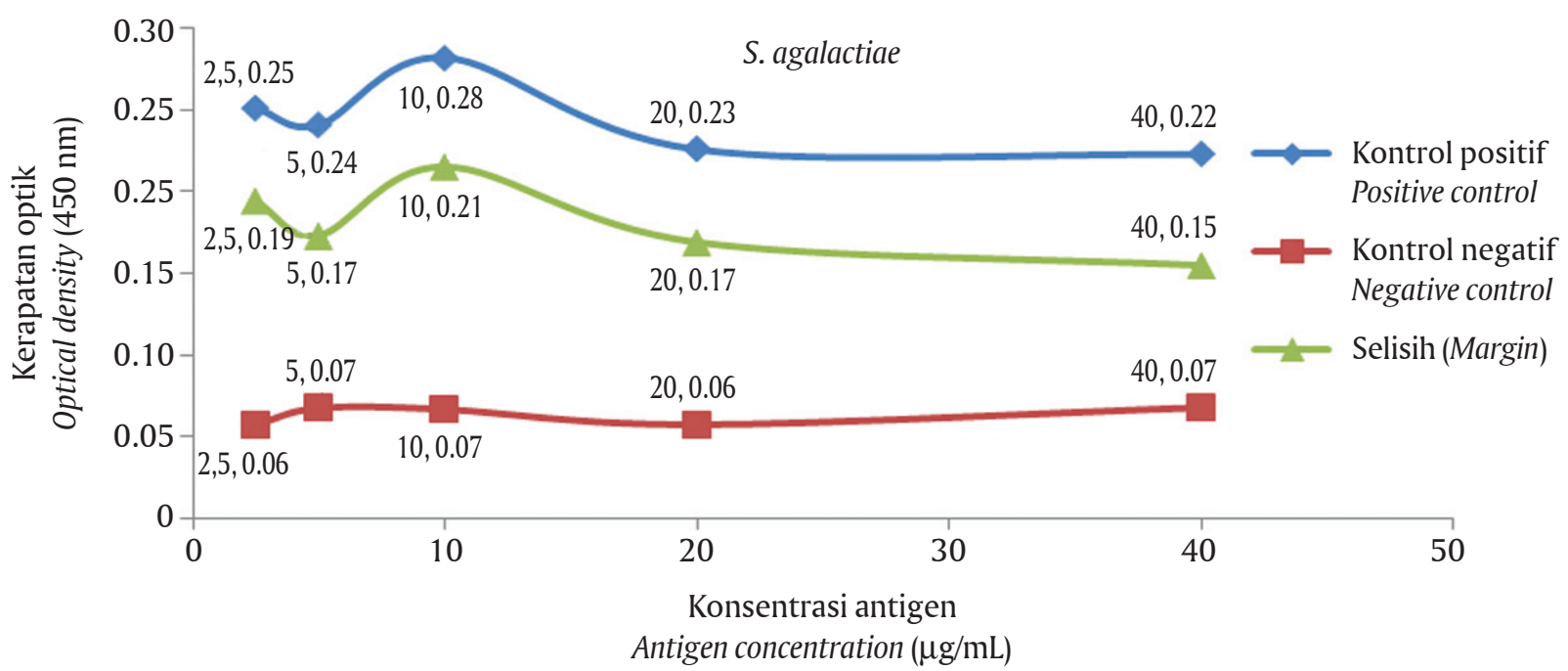

Gambar 2. Nilai OD ELISA serum kontrol positif dan kontrol negatif ikan nila pada berbagai pengenceran antigen $S$. agalactiae

Figure 2. The value of OD ELISA for positive and negative controls serum of tilapia at various dilutions of antigen $S$. agalactiae

na itu informasi mengenai konsentasi antigen optimal sangat diperlukan. Konsentrasi antigen merupakan salah satu faktor pembatas dalam uji ELISA (Botus \& Oncescu, 2006).

\section{Tahap II}

Antibodi serum ikan nila yang divaksinasi dengan vaksin koktail $A$. hydrophila dan S. agalactiae melalui perendaman telah diukur dengan ELISA. Hasil pengujian titer antibodi ikan nila disajikan pada Gambar 3.
Gambar 3 menunjukkan nilai titer antibodi ikan nila sebelum vaksinasi, selama masa induksi kekebalan setelah vaksinasi, dan setelah uji tantang. Kelompok yang divaksinasi memiliki titer antibodi yang lebih tinggi daripada kontrol. Pada minggu pertama, titer antibodi kelompok ikan yang divaksinasi tidak berbeda nyata dengan kontrol ( $p>0,05)$. Minggu kedua sampai minggu kelima, tingkat antibodi kelompok vaksinasi secara signifikan lebih tinggi dibanding kontrol $(\mathrm{P}<0,05)$, meskipun pada minggu ke-
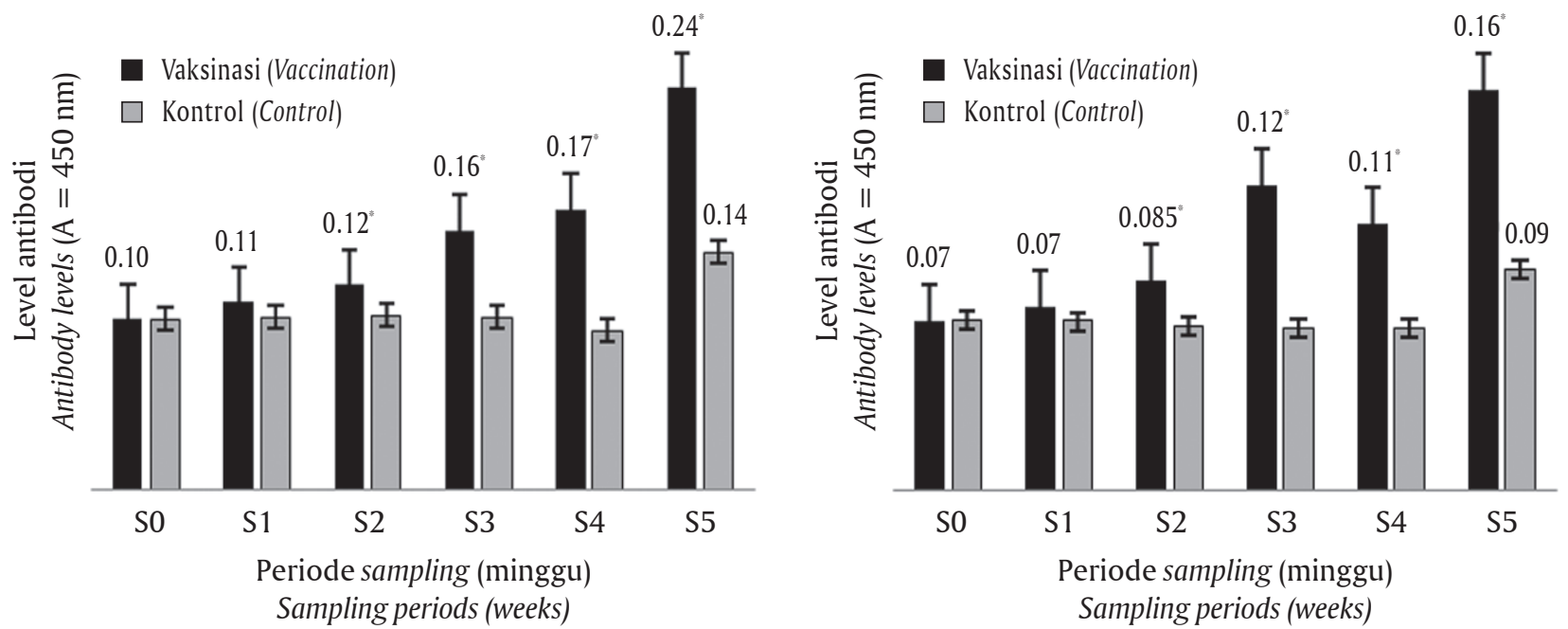

Gambar 3. Titer antibodi dari serum ikan nila dengan pelapisan antigen A. hydrophila (kiri) dan S. agalactiae (kanan). Vaksinasi $=$ Sampel serum ikan yang divaksinasi; Kontrol $=$ Sampel serum ikan kontrol; S0 $=$ Sebelum vaksinasi; S1, S2, S3 = Masa induksi kekebalan setelah vaksinasi; S4, S5 = Periode setelah uji tantang. (" Berbeda nyata dengan kontrol, $t$ student-test, $\mathrm{p}<0,05$ )

Figure 3. Serum antibody titers of tilapia with antigen coating of A. hydrophila (left) and S. agalactiae (right). Vaccination = Sample from vaccinated fish; Control = Serum from control fish; SO = Before vaccination; S1, S2, S3 = Induce time of immunity post-vaccination; S4, S5 = Post challenge test period. ( Significantly different with control, $t$ student-test $P<0.05)$ 
tiga titer antibodi sempat turun baik terhadap A. hydrophila maupun $S$. agalactiae. Secara statistik, hasil penelitian menunjukkan bahwa konsentrasi antibodi spesifik ikan yang divaksinasi secara signifikan lebih tinggi daripada kontrol baik terhadap A. hydrophila maupun $S$. agalactiae. Hal tersebut menunjukkan bahwa antigen yang dimasukkan bersifat antigenik karena mampu menginduksi respon imun dengan peningkatan nilai titer antibodi pada kelompok perlakuan. Tetapi hal yang lebih penting bahwa antibodi yang dihasilkan harus bersifat imunogenik dan protektif, yaitu antibodi yang dihasilkan mampu memproteksi inang dari paparan antigen homolog (Wibawan \& Soejoedono, 2013).

Ikan bergantung pada sistem kekebalan tubuh mereka untuk menjaga kesehatan, dan menghasilkan antibodi sebagai respon terhadap infeksi oleh organisme patogen (virus, bakteri, jamur, parasit), atau vaksinasi. Vaksinasi bertujuan untuk menginduksi imunitas jangka panjang dengan merangsang komponen dari respon imun spesifik. Metode pemberian vaksin melalui perendaman bertujuan untuk mengekspose permukaan tubuh ikan secara langsung terhadap larutan vaksin mengandalkan daya serap terutama oleh insang yang memiliki kemampuan imbibisi (peristiwa penyerapan air oleh permukaan zatzat yang hidrofilik (Ellis, 1988). Terbentuknya respon imun spesifik (antibodi) dimulai dari masuknya antigen dalam hal ini A. hydrophila dan S. agalactiae ke dalam tubuh ikan kemudian difagosit oleh makrofag. Makrofag akan memberikan rangsangan ke sel limfosit untuk memproduksi antibodi sesuai jenis antigen yang masuk. Pembentukan antibodi tersebut dipengaruhi oleh beberapa faktor antara lain suhu, dosis vaksin, cara pemberian vaksin, umur dan bobot ikan serta sifat antigen (Tizard, 1988; Ellis, 1988). Metode ELISA memiliki keunggulan yaitu sederhana, sensitif, efektif dan murah (Ostland et al., 2008) yang dapat digunakan untuk mendeteksi antibodi.

ELISA adalah tes sensitif yang bergantung pada deteksi antigen dengan antibodi, dan perubahan enzimatik warna berkorelasi dengan kehadiran antigen. Akurasi terhadap hasil ELISA ditentukan oleh beberapa faktor antara lain ditentukan cara preparasi dan konsentrasi antigen yang digunakan (Ostland et al., 2008). Romstad et al. (2012) menyebutkan bahwa selain konsentrasi antigen, metode preparasi antigen juga menentukan terhadap hasil titer antibodi. Sugiani et al. (2014) menyampaikan bahwa preparasi antigen untuk deteksi antibodi terhadap S. agalactiae yang paling baik diperoleh produk ekstra seluler yang disonikasi. Metode ini dapat digunakan untuk mengukur respon antibodi dan dapat digunakan untuk memastikan ikan yang dilindungi dari berbagai patogen atau pengaruh vaksinasi terhadap respon imun ikan.
Sukenda dan Wakabayashi (2002) berkesimpulan bahwa, prosedur indirect-ELISA cukup sensitif untuk mendeteksi antibodi serum Plecogiossus altivelis yang divaksinasi dengan bakterin dengan metode perendaman.

Evaluasi vaksin dan tes serologi yang berhubungan dengan kekebalan protektif akan menjadi alternatif yang dapat dilakukan untuk pengujian. Metode konvensional untuk estimasi antibodi pada ikan, seperti aglutinasi serum hanya dapat dilakukan ketika tingkat antibodi yang dihasilkan relatif tinggi. Untuk mendeteksi respon antibodi dengan konsentrasi yang kurang atau sangat kecil, metode yang lebih sensitif akan lebih membantu memberikan hasil yang optimal. Oleh karena itu, ELISA dikembangkan untuk mendeteksi antibodi terhadap $A$. hydrophila dan $S$. agalactiae pada ikan nila setelah vaksinasi. Adanya antibodi spesifik yang lebih tinggi dalam populasi ikan setelah vaksinasi menunjukkan bahwa seluruh populasi dapat dilindungi dengan adanya vaksinasi. Dengan melakukan optimasi konsentrasi antigen dalam ELISA memungkinkan untuk mendeteksi antibodi spesifik dari semua ikan yang divaksinasi terhadap vaksin koktail A. hydrophila dan S. agalactiae.

\section{KESIMPULAN DAN SARAN}

Kesimpulan dari hasil penelitian ini yaitu konsentrasi optimum antigen $A$. hydrophila dan $S$. agalactiae untuk penentuan antibodi pada ikan nila dengan menggunakan indirect-ELISA masing-masing sama yaitu sebesar $10 \mu \mathrm{g} / \mathrm{mL}$. Konsentrasi tersebut dapat digunakan untuk mendeteksi antibodi spesifik terhadap A. hydrophila dan S. agalactiae pada ikan nila yang divaksinasi.

\section{UCAPAN TERIMA KASIH}

Ucapan terima kasih disampaikan kepada program beasiswa KKP atas pendanaan untuk penelitian ini, juga dukungan dari Balai Penelitian dan Pengembangan Budidaya Air Tawar Bogor dan fasilitas laboratorium uji BPPBAT sehingga penelitian bisa diselesaikan dengan baik. Penghargaan yang tinggi dihaturkan untuk Ir. Taukhid, M.Sc., Dr. Desy Sugiani, M.Si., Saudara Edy Farid W., Bambang Priadi, dan Ahmad Wahyudi.

\section{DAFTAR ACUAN}

Bradford, M.M. (1976). A rapid and sensitive method for the quantitation of microorganisms quantities of protein in utilizing the principle of protein dye binding. Anal. Biochem, 72: 248254.

Botus, D., \& Oncescu, T. (2006). Optimizing immunoenzymatic reactions (ELISA) for the detection of antibody against NDV virus. Analele Universitã 
Nii din Bucuresti-Chimie, Anul XV (serie nouã), II: 33-41.

Crowther, J.R. (1995). ELISA: Theory and Practice. Methods in Molecular Biology. Totowa, NJ. Humana Press, 223 pp.

Ellis, A.E. (1988). Current aspects of fish vaccination. Dis. Aquat. Org., 4: 159-164.

Estevez, J., Leiro, J., Toranzo, A.E., Barja, J.L., \& Ubeira, F.M. (1994). Kinetics of antibody production against Vibrio anguillarum antigens in turbot. Aquaculture, 123: 191-196.

Ibrahem, M.D., Arab, R.M.H., Mostafa, M.M., \& Rezk, M.A. (2008). Evaluation of different vaccination strategies for control of mass in nile tilapia 0 . niloticus. In: Egypt. $8^{\text {th }}$ International Symposium on Tilapia in Aquaculture 2008, 1157-1175.

Irianto, A. (2003). Patologi Ikan Teleostei. Gadjah Mada University Press. Yogyakarta, $256 \mathrm{hlm}$.

Lubis, H.A. (2013). Crude antigen Cystisercus taenia saginata isolate local Bali untuk deteksi sistiserkosis pada sapi [Tesis]. Sekolah Pascasarjana. Universitas Udayana, $60 \mathrm{hlm}$.

Lusiastuti, A.M., Gardenia, L., Mufidah, T., \& Aryati, Y. (2009). Streptococcus agalactiae infection on tilapia (Oreochromis niloticus) in Cirata Reservoir of West Java. Indonesian Aquaculture Journal, 4(1): 4751.

Ostland, V., Alcom, S., LaPatra, S., Harbell, S., Friedman, C., \& Winton, J. (2008). Measurement of Rainbow Trout and Hybrid Striped Bass Antibody Using an Enzyme-Linked Immunosorbent Assay (ELISA). WRAC Publications, 8 pp.

Pasnik, D.J., Evans, J.J., Panangala, V.S., Klesius, P.H., Shelby, R.A., \& Shoemaker, C.A. (2005). Antigenicity of Streptococcus agalactiae extracellular products and vaccine efficacy. Journal of Fish Diseases, 28: 205-212.

Romstad, A.B., Reitan, L.J., Midtlyng, P., Gravningen, K., \& Evensen, O. (2012). Development of an antibody ELISA for potency testing of furunculosis (Aeromonas salmonocida subsp salmonicida) vaccines in Atlantic salmon (Salmo salar L). Biologicals, 40: 67-71.

Romstad, A.E., Reitan, L.J., Midtlyng, P., Gravningen, K., Emilsen, V., \& Evensen, O. (2014). Comparision of a serological potency assay for furunculosis vaccines (Aeromonas salmonicida subsp. salmonicida) to intraperitoneal challenge in Atlantic salmon (Salmo salar L.). Biologicals, 42: 86-90.

SNI [Standar Nasional Indonesia]. (2006). Cara Uji Mikrobiologi-Bagian 3: Penentuan angka lempeng total (ALT) pada produk perikanan. BSN. Jakarta. SNI: 01-2332.3-2006, $14 \mathrm{hlm}$.

Siti-Zahrah, A., Padilah, B., Azila, A., Rimatulhana, R.,
\& Shahidan, H. (2008). Multiple streptococcal species infection in cage-cultured red tilapia but showing similar clinical signs, In: BondadReantaso, M.G., Mohan, C.V., Crumlish, M. and Subasinghe, R.P, (eds.). Diseases in Asian Aquaculture VI. Fish Health Section, Asian Fisheries Society, Manila, Philippines, p. 313-320.

Sugiani, D. (2012). Vaksin bivalen untuk pencegahan penyakit motile aeromonas septicemia dan streptococcis pada ikan nila. [Disertasi]. Institut Pertanian Bogor. Bogor, $163 \mathrm{hlm}$.

Sugiani, D., Sukenda, Harris, E., \& Lusiastuti, A.M. (2012). Respons imun ikan tilapia, Oreochromis niloticus, terhadap vaksin bivalen sel utuh dan ekstra selular antigen Aeromonas hydrophila dan Streptococcus agalactiae. Dalam Prosiding Forum Inovasi teknologi Akuakultur 2012, hlm. 755-763.

Sugiani, D., Lusiastuti, A.M., \& Wiratama, E. (2014). Pengembangan Metode Indirect Enzyme-Linked Immunosorbent Assay (ELISA) Untuk Mengukur Respons Imun Humoral Ikan Nila, Oreochromis niloticus Terhadap Antigen Streptococcus agalactiae, dalam: Prosiding Forum Inovasi Teknologi Akuakultur 2014, Bandung 6-8 Mei 2014, hlm. 10691074.

Sukenda, \& Wakabayashi, H. (2002). Use of An Indirect Enzyme-Linked Immunosorbent Assay (ELISA) To Detect Antibodies In Ayu (Plecogiossus altivelis) Vaccinated By Immersion Administration. Jurnal Akuakultur Indonesia, 1(1): 27-30.

Sumiati, T., Lusiastuti, A.M., \& Taukhid. (2012). Pengembangan vaksin cocktail (A. hydrophilaS. agalactiae) melalui rendaman dan pakan untuk pencegahan penyakit potensial pada budidaya ikan nila. Seminar Hasil Riset BPPBAT Bogor 4-5 Desember 2012.

Supriyadi, H., Widiyati, A., Sunarto, A., \& Prihadi, T.H. (2005). Keragaan penyakit bakterial ikan nila (Oreochromis niloticus) pada keramba jaring apung (KJA) di lokasi berbeda. Jurnal Penelitian Kelapa Sawit, 11(7): 35-45.

Tengjaroenkul, B., \& Yowarach, S. (2009). Research Article: Efficacy of vaccine combined freudus complete adjuvant to prevent streptococcosis in nile tilapia. KKU Vet J. 19(2):188-196. (15 September 2011).

Thuvander, A., Hongslo, T., Jansson, E., \& Sundquist, B. (1987). Duration of protective immunity and antibody titres measured by ELISA after vaccination of rainbow trout, Salmo gairdneri Richardson, against vibriosis. Journal of Fish Diseases, 10: 479486.

Tizard, I.R. (1988). Pengantar Immunologi Veteriner. Partodiredjo, M. Penerjemah; Hardjosworo, S. 
editor. Penerbit Universitas Airlangga Surabaya. 1987. Terjemahan dari An Introduction to Veterinary Immunology, $497 \mathrm{hlm}$.

Toranzo, A.E., Romalde, J.L., Magarinos, B., \& Barja, J.L. (2009). Present and future of aquaculture vaccines against fish bacterial diseases. The use of veterinary drugs and vaccines in mediteranean aquaculture. Options Méditerranéennes, A/no. 86: 155-176.

Vivas, J., Razquin, B., Lopez-Fierro, P., \& Villena, A.J. (2005). Modulation of the immune response to an Aeromonas hydrophila aroA live vaccine in rain- bow trout: effect of culture media on the humoral immune response and complement consumption. Fish \& Shellfish Immunology, 18: 223-233.

Wibawan, I.W.T., \& Soejoedono, R.D. (2013). Intisari Imunologi Medis. Fakultas Kedokteran Hewan IPB. Bogor, $157 \mathrm{hlm}$.

Zheng, Z., Yingeng, W., Qingyin, W., Nannan, D., Meijie, L., Jiangbo, Q., Bin, L., \& Lan, W. (2012). Study on the immune enhancement of different immunoadjuvants used in the pentavalent vaccine for turbots. Fish \& Shellfish Immunology, 32: 391395. 